\title{
Profile and sexual practices of inmates in a correctional service facility in north-west Nigeria
}

\author{
Asma'u Usman, ${ }^{1}$ Aishatu Yusha'u Armiya'u, ${ }^{2}$ Zubairu Iliyasu ${ }^{3}$ \\ ${ }^{1}$ Department of Pathology, Federal Medical Center Katsina, Katsina State; ${ }^{2}$ Department of Psychiatry, \\ Forensic Psychiatry Unit, Jos University Teaching Hospital, Plateau State; ${ }^{3}$ Department of Community \\ Medicine, Bayero University Kano, Kano State, Nigeria
}

\begin{abstract}
Prisoners are not exempted from sexual desire. Therefore, sexual activity is continuous in various forms behind bar, regardless of the stringent rules. However, little is known about such behaviours during incarceration in Katsina State, Nigeria. This study aimed to determine the sociodemographic and forensic characteristics as well as sexual practices among prison inmates in Katsina. A descriptive cross-sectional study was done to collect data of 216 inmates using semi-structured questionnaires from September $24^{\text {th }}$, 2018 to November $9^{\text {th }}, 2018$ (6 weeks) at Katsina Central Correctional Service. Data was analyzed using IBM Statistical Package for Social Sciences software (SPSS) Version 20. The mean ( \pm Standard deviation, SD) ages of respondents were $31.5 \pm 10.9$ years. Most of the respondents (94\%) were male, almost
\end{abstract}

Correspondence: Aishatu Yusha'u Armiya'u, Department of Psychiatry, Forensic Psychiatry Unit, Jos University Teaching Hospital, Plateau State, Nigeria.

Tel.: +2348035899338

E-mail: aarmiyau@gmail.com

Key words: Correctional service; inmates; Nigeria; sexual desire.

Conflict of interest: The authors declare no conflict of interest.

Ethical approval and consent to participate: The study was approved by the Katsina State Health Research Ethical Review Committee (HREC) with approval number MOH/ADM/SUB/1152/1/262. Participants provided their consent to participate.

Consent for publication: Written informed consent was obtained from a legally authorized representative(s) for anonymized patient information to be published in this article.

Availability of data and materials: The datasets used and analyzed during the current study are available from the corresponding author on reasonable request.

Received for publication: 3 January 2021.

Revision received: 22 January 2021.

Accepted for publication: 22 January 2021.

This work is licensed under a Creative Commons Attribution NonCommercial 4.0 License (CC BY-NC 4.0).

CCopyright: the Author(s),2020

Licensee PAGEPress, Italy

Annals of African Medical Research 2020; 3:139

doi:10.4081/aamr.2020.139 half of them (44.4\%) had secondary school education, more than half $(55.1 \%)$ were into business or trading and the majority $(75.9 \%)$ were awaiting trial. Nearly all inmates $(98.6 \%)$ reported having sexual desire. Watching the nakedness of others $(44.4 \%)$ and masturbation $(38 \%)$ were the commonest means of sexual expression and satisfaction of sexual desire while in prison. The study found predominant male inmates who were within the reproductive and sexually active age group, with secondary school education and unemployed. The majority had sexual desires, with watching nakedness of others and masturbation as the commonest means of satisfying their sexual desires. Correctional facility authorities should implement sexual health programs for inmates and consider conjugal visitations/furloughs.

\section{Introduction}

Globally, $93 \%$ of prisoners are males, while $6.5 \%$ are women. ${ }^{1}$ In Nigerian prisons, less than $4 \%$ of total admissions are females, with the majority serving short-term prison terms and $50 \%$ of them between the ages of 20 and 50 years. ${ }^{2}$ Many prisoners lead degrading and dehumanising sex lives when incarcerated because of sexual deprivation regardless of their sexual orientation. ${ }^{3}$ Sexual desire, in prison, often accompanies an unsatisfied state. Results from Kano, Nigeria show that $82.5 \%$ of inmates have sexual desire. ${ }^{4}$ The consequences of sexual deprivation results in various forms of consensual and non-consensual sex. This may be in the form of exploitive sex, homosexual satisfaction, sexual abuse or victimization..$^{5}$ The consequences of sexual deprivation not only affect inmates but extends to their spouses and loved ones as they await their release. ${ }^{5}$ The effect of consequences of sexual deprivation is usually devastating and affect victims physically, emotionally, socially and spiritually. ${ }^{5}$ The predominantly Hausa-Muslim structure in the locality of the study usually puts a damper on the sexuality and sexual needs of inmates. Prior to incarceration, most prison inmates engage in risky sexual practices such as homosexuality, unprotected sex with multiple partners, transactional sex, sexual violence, commercial sex work, drug abuse, sex in exchange for drugs and impaired judgement from drug intoxication. ${ }^{6}$ In gender exclusive environment, as in the case in prison, homosexuality is widespread behind the walls and the Nigerian prison is no exception. ${ }^{7}$ Most inmates are circumstantial homosexuals and are lured by others due to lack of basic necessities and proper nutrition. ${ }^{7}$ Homosexuality ranged from $1.4-82.2 \%$ in Nigerian prisons. ${ }^{4,7-9}$ Overcrowding, congestion and inadequate prison staff promote these illicit sexual behaviours amongst inmates. ${ }^{8}$ This is the norm in Katsina State. ${ }^{10}$

The congestion rate in prisons is high in Nigeria $-400 \%$ in Ibara prison, Abeokuta, Ogun State and 300\% in Oko prison, Benin City, Edo State. The most congested prisons in Nigeria are in Anambra, Lagos, Delta, Edo, Enugu, Kaduna, Katsina, Rivers States and FCT. ${ }^{11}$ The total capacity of the Katsina Correctional Service is 400 but there are currently more than 1500 inmates. ${ }^{12}$ This congestion in the Nigerian prisons can be attributed to undue delay in trial. 


\section{Materials and Methods}

\section{Study location}

The study is conducted in Katsina Central Correction Service, one of the eleven Correctional Services in the state, because of its heterogeneity in that it contains inmates of both sexes and varied sentences as it is located in a metropolitan town. It serves both males and females with a capacity of about 400 but this has been stretched to more than 1,500 inmates in recent times. ${ }^{12}$

\section{Study design}

The study is descriptive cross-sectional in design to collect data from respondents.

\section{Study population}

The study population comprised of all inmates who have been in prison for at least a month in Katsina Central Correctional Service.

\section{Inclusion criteria}

i) A prison inmate, male and female, who had been in prison for at least a month; ii) A prison inmate who provided voluntary informed consent to participate in the study.

\section{Exclusion criteria}

i) Any mentally unstable inmate or one who was on treatment for psychiatric disorders; ii) Inmates who were very sick and/or were on admission in the prison clinic.

\section{Sample size determination}

The sample size for quantitative study was calculated using the Fisher's formula for descriptive cross-sectional studies. ${ }^{13}$

$$
\mathrm{n}=\frac{\mathrm{Z}^{2} \mathrm{Pq}}{\mathrm{d}^{2}}
$$

where:

$\mathrm{n}=$ Minimum sample size for the study

$\mathrm{Z}=$ Standard normal deviate corresponding to the probability of type I error $(\propto)$ at $5 \%=1.96$

$\mathrm{P}=$ Prevalence of sexual activity among prison inmates $(14.9 \%)$ obtained from a previous study ${ }^{4}=0.149 \approx 0.15$

$\mathrm{q}=$ Complementary probability which is $1-\mathrm{p}=1-0.15=0.85$.

$\mathrm{d}=$ Degree of precision of $5 \%$

Therefore

$$
\mathrm{n}=\frac{(1.96)^{2} \times(0.15 \times 0.85)=196}{\left(0.05^{*} 0.05\right)}
$$

Ten percent (10\%) was added to the minimum sample size to account for non-response; hence a total of 216 eligible respondents were recruited into the study.

\section{Study instruments}

An interviewer administered, pre-tested, semi-structured questionnaire adapted from a study in New South Wales ${ }^{14}$ and modified to suit the objectives of this study was used for data collection.

The questionnaire had three sections and sought information on socio-demographic characteristics, forensic characteristics and sexual activity of inmates

\section{Data analysis}

All data were entered into a Microsoft excel sheet and rechecked for entry errors and the data were cleaned prior to analysis. When necessary, the questionnaire was traced to verify inconsistent or missing data. Data were analyzed using IBM Statistical Package for Social Sciences software (SPSS) Version 20. Quantitative data were summarized using mean \pm standard deviation or the median and range depending on the distribution. Categorical data were presented as frequencies and percentages in tables and charts. At the bivariate level, Pearsons's chi-square and Fisher's exact tests were used, as appropriate, to test for the significance of associations, with $\mathrm{p}<0.05$ considered significant.

\section{Results}

\section{Socio-demographic characteristics of respondents}

The age of the respondents ranged from 17-85 years with a mean age ( \pm Standard Deviation, SD) of $31.5 \pm 10.9$ years. Most of the respondents (94\%) are males. The majority (91.2\%) of the respondents were Muslims, of the Hausa tribe (82.9\%) and married $(50.9 \%)$. About half of the respondents $(44.4 \%)$ had secondary level of education while a quarter $(25.9 \%)$ had only Qur'anic education. Less than a quarter $(22.7 \%)$ of them had tertiary education. Most respondents (55.1\%) were into trading or business while over a third (39.8\%) were unemployed (Table 1)

Table 1. Socio-demographic characteristics of inmates in Katsina Correctional Service.

\begin{tabular}{lcc} 
Socio-demographic Characteristics & $\begin{array}{c}\text { Frequency } \\
\text { (n) }\end{array}$ & $\begin{array}{c}\text { Percentage } \\
(\%)\end{array}$ \\
\hline Age (Years) & & \\
Mean Age \pm SD & $31.5 \pm 10.9$ & \\
<24 & 55 & 25.5 \\
$25-34$ & 97 & 44.9 \\
$35-44$ & 38 & 17.6 \\
$45-54$ & 17 & 7.8 \\
>55 & 9 & 4.2 \\
Gender & & \\
Male & 203 & 94 \\
Female & 13 & 6 \\
\hline Religion & & \\
Islam & 197 & 91.2 \\
Christianity & 19 & 8.8 \\
Tribe & & \\
Hausa & 179 & 82.9 \\
Fulani & 16 & 7.4 \\
Others* & 21 & 9.7 \\
\hline Marital Status & & \\
Married & 110 & 50.9 \\
Single & 91 & 42.1 \\
Widowed/Divorced & 15 & 7 \\
Level of education & & \\
Quranic & 56 & 25.9 \\
Primary & 119 \\
Secondary & 12 & 5.6 \\
Tertiary* & 96 & 44.4 \\
Adult education & 49 & 22.7 \\
\hline Occupation & 3 & 1.4 \\
Civil servants & & \\
Trading/Business* & & 55.1 \\
Unemployed & & 39.8 \\
Key* & & \\
\hline
\end{tabular}

*Others = Ibo, Yoruba, Berom, Igbira, Kanuri; ${ }^{*}$ Trading/Business = farmers, welders, carpenters masonry, drivers, electricians, plumbers, herdsmen, labourers, petty traders; *Tertiary education = Diploma, Undergraduate degree, Postgraduate degree. 


\section{Forensic profile of respondents}

Table 2 displays the length of sentence among inmates. The majority $(75.9 \%)$ of inmates were awaiting trial while $9.3 \%$ and $5.6 \%$ of them were incarcerated for misdemeanour and felony respectively. Inmates serving life and death sentences accounted for $4.6 \%$ each of the overall prison population sampled.

Figure 1 is a bar chart showing the reasons for imprisonment of inmates in the central prison of Katsina. The most common reasons were armed robbery (22.2\%), murder (19.4\%), theft (18.5\%) and drugs $(11.6 \%)$ while the least common include harbouring theft items, hoarding culprits and pimping each accounting for $0.5 \%$ each.

Figure 2 shows the sexual orientation of inmates. The majority $(82.9 \%)$ of the inmates were straight while $6.9 \%$ of them indicated that they were homosexuals, while $9.7 \%$ were undisclosed about their sexual orientation being. Only $1(0.5 \%)$ inmate identified himself as bisexual.

\section{Sexual practices and choices of inmates at Katsina Correctional Service}

Table 3 depicts the sexual experiences of inmates within the confines of the central prison in Katsina metropolis. Two hundred and thirteen inmates (98.6\%) admitted to feeling sexual desire with $83.3 \%$ of them for women, $20 \%$ for men and $16 \%$ for both men and women. Less than half $(44.4 \%)$ of the inmates confessed to feeling sexual desire by watching the nakedness of others and onethird (38\%) by masturbation. About two-third of inmates admitted to satisfying their desires by watching the nakedness of others (38.7\%) and masturbating (37.8\%). A fraction of inmates $(6.1 \%$, 14 out of 216) admitted to multiple methods of satisfying themselves. Substantial proportions (42.1\%) of inmates were aroused in prison by watching the nakedness of others. It is the most common method (25.5\%) of getting aroused followed by sexual talks (13.4\%). The motives for sexual relations within the confines of prison ranged from curiosity $(18.1 \%)$, to loneliness $(17.1 \%)$ and coercion $(0.9 \%)$.

\section{Discussion}

The socio-demographic characteristics of inmates in Katsina Correctional Service show a preponderance of males. According to the World prison population list, $93 \%$ of prison inmates are male. ${ }^{1}$ Men are more likely to commit offenses that result in prison sentences. Violence is frequent and widespread in prisons that contain male inmates, and as a result, detailed hierarchical social structures

Table 2. Length of sentence of prison inmates.

\begin{tabular}{lcc} 
Length of sentence & Frequency ( $\mathrm{n})$ & Percentage (\%) \\
Awaiting trial & 164 & 75.9 \\
Misdemeanour* & 20 & 9.3 \\
\hline Felony & 12 & 5.6 \\
Life & 10 & 4.6 \\
\hline Death sentence & 10 & 4.6 \\
Total & 216 & 100 \\
\hline Key* & &
\end{tabular}

Misdemeanour: 6 months/3 years, Felony: 37 months/21 years. are created. Male inmates often belong to prison gangs to obtain protection and security. This is in keeping with what is obtained locally and globally. ${ }^{11,15,16}$ The overall pattern is that two-thirds of inmates in the index study are below the age of 35 years which are thought to be the most sexually active as well as the ones most likely to engage in risky sexual behaviours. This portrays the characteristic age range of prisoners in Nigeria. ${ }^{2}$ They are also within the productive age (work force) and is in concordance with the epidemiology of crime. This is similar to findings from studies in Nigeria and USA. ${ }^{7,17-19}$ Majority of the inmates are of the HausaFulani descent. This may be attributed to the locality of which the study took place. About half of the inmates in this study $(50.9 \%)$ are married, while a large proportion of the remainder (42.1\%) are single. Most of the inmates were Muslims (91.2\%). This is a reflection of the dominant religious practice in the Correctional

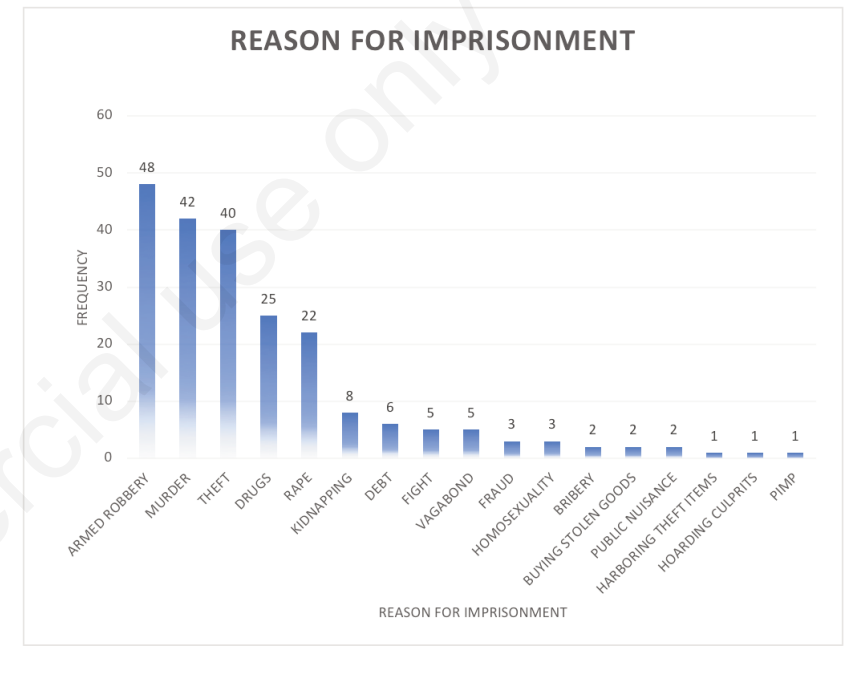

Figure 1. Bar chart showing reason of imprisonment of inmates.

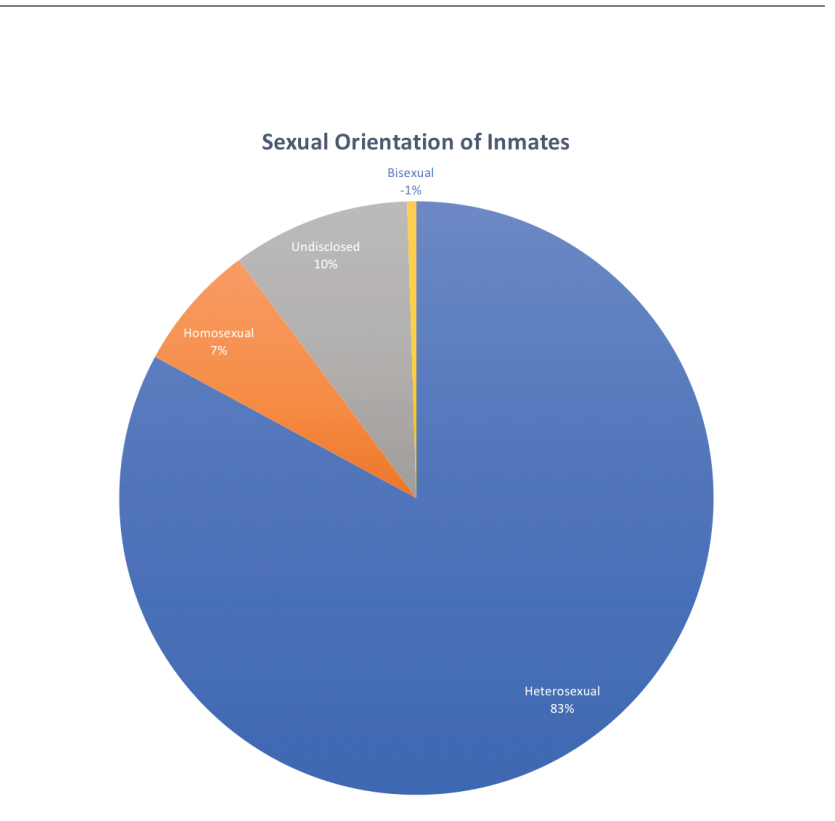

Figure 2. Pie chart showing sexual orientation of inmates. 
facilities catchment population. More than half of inmates (44.4\%) have secondary level of education before incarceration and were into trading and/or business while about a third of them are unemployed. This contrast with the findings by Audu et al. in Kaduna State North-western Nigeria and Fadare et al. in Akure, Ondo State Nigeria where about $51.4 \%$ and $51 \%$ of inmates respectively were secondary school dropouts and very high level of unemployment before incarceration. ${ }^{19-21} \mathrm{~A}$ previous study by Odujinrin and Adebajo in Lagos State Nigeria in 1997 revealed a similar finding to the index study where $52 \%$ of inmates had secondary school education. $^{22}$ It is saddening on the length of stay of inmates in Nigerian Correctional services. The index study revealed that $75.9 \%$ of inmates are awaiting trial. This is similar to what was found in other parts of Nigeria. ${ }^{23-24}$ This is probably due to delay and complexity of the judiciary system in the country. Available data on the rate of awaiting trial persons for different countries show that the Nigerian figure is high - Japan (11.3\%), Malawi (12.3\%), United Kingdom (12.9\%), South Africa (20.2\%), USA (21.5\%), Malaysia (21.6\%), Ghana (22.6\%), Egypt (41.4\%) and Cameroon $(60.7 \%) .{ }^{25}$ Five out of the ten countries in the world with most pre-trial detainees are African countries. ${ }^{26}$

The three highest occurring offences were armed robbery, murder and theft in index study. This is similar to a study by Armiya'u et al. in Jos, Nigeria that revealed identical findings. ${ }^{26}$ The high proportion of violent crimes may be explained by the fact that the study was conducted in a medium security Correctional service facility. A similar finding was found in a hospital-based study where murder was the commonest offence. ${ }^{27,28}$ In contrast, find-

Table 3. Summary of sexual experiences of inmates in Katsina Correctional service.

Sexual variable

Feeling sexual desire

Yes

Sexual desire with whom

Both men and women

Men

Women

Frequency (n)

Percentage (\%)

Mode of sexual desire

Celibacy

Consensual sex

Exposing nakedness to others

Masturbation

Touching of genitals

Watching nakedness of others

ode of satisfaction

Anal sex

Celibacy

Mutual anal insertion

Masturbation

Putting fingers in anus

Masturbation, anal sex

Masturbation, anal sex, oral sex, putting fingers in anus

Masturbation, oral sex

Masturbation, putting fingers in anus

Touching of genitals

Watching nakedness of others

Watching nakedness of others, anal sex

Watching nakedness of others, fingers in anus

Watching nakedness of others, masturbation

Arousal

Yes

No

How they got aroused?

Sexual talks

Watching others naked

Sexual thoughts

Looking at others

Seeing women in clinic

Wet dreams

Nil

Touching each other

Motive for sexual relations within the prison

Celibacy

Coercion

Curiosity

Economic manipulation

Loneliness

Nil

Peer pressure
213

98.6

7.4

9.3

83.3

180

180

.

12

$\begin{array}{ll}26 & 12 \\ 1 & 0.5 \\ 1 & 4 .\end{array}$

$10-4.6$

$82-38$

100.5

$96-44.4$

2.2

$26-11.3$

$1-0.4$

$87-37.8$

3

$2-1.0$

$1-0.4$

$2-1.0$

$1-0.4$

$10-4.3$

$89-38.7$

1

$1+0.4$

1 0.4

125

$91 \quad 57.9$

$29-13.4$

$55-25.5$

$27-12.5$

0.5

$1 \quad 0.5$

100

1

0.5

$1 \quad 0.5$

20.9

$39-18.1$

$6-2.8$

$37-17.1$

$127-58.8$

4
270.9 
ings from other studies in Nigeria differed from index study. ${ }^{17,29-30}$

Sexual desire is, at its most literal, the feeling that accompanies an unsatisfied state. According to clinical psychologist, sexual desire is a bodily urge more analogous to hunger or the blood's need for oxygen. ${ }^{31}$ It is thus one of the - if not the strongest of human needs. ${ }^{31}$ In a book review, a researcher described sexual desire as an existential need that is universal for all types of gender and leaves a person with an emptiness that is usually fulfilled through a desired gender. ${ }^{32}$ This study revealed that almost all the respondents $(98.6 \%)$ reported having sexual desire with about three-quarters of them having it for women. This is similar to what was found in a study conducted in Kano central Correctional service, North-western Nigeria where $82.5 \%$ of inmates reported having frequent sexual desire. ${ }^{4}$

Sexual practices inside prison occurs with utmost secrecy and low levels of disclosure and openness on the subject amongst inmates, more especially to outsiders. ${ }^{33}$ The four most common means by which inmates in the index study expressed their sexual desire were touching of genitals (self or others), masturbation, celibacy and exposing their nakedness to others. This is similar to what was found in other studies across Nigeria. ${ }^{4,7,15}$ The options for satisfying this desire was majorly by watching the nakedness of others followed by masturbation, celibacy and touching of others. This is in keeping with what was found in the Kano study. ${ }^{4}$ Homosexuality was rare in this study. This may be attributable to the fact that many inmates were unwilling to admit to such behaviour for fear of further disciplinary action as homosexuality is a criminal offence in Nigeria and carries an additional 14 years jail term unlike in many Western countries where it is legal. Various studies, some of which are from Scottish prisons and Arthur Road Jail in India, also reported a low rate of reported homosexuality which they attributed to non-acceptance of homosexuality in prison population and limited opportunity for sexual activity in prison. ${ }^{34-35,19}$ However, some studies in Nigerian prisons revealed homosexuality as the commonest sexual practice. ${ }^{15}$ This could be facilitated in prison due to overcrowding. In many prisons, men are crowded into cells with one another, often resulting in a lack of privacy. Inmates can watch other inmates change clothes, use the bathroom, and take showers. Situations like this create an impossible environment for officials to control. Older, more experienced inmates use the overcrowded situation to their advantage by exploiting the younger, more naive inmates.

This study had limitation. First, this study was conducted in only one of the eleven correctional facilities in the State, there could be variations from other facilities within the state. Second, cultural inhibitions or fear of reprimand could result in socially acceptable responses introducing social desirability bias. Nonetheless the study provides insight into the sexual lives of the mostly ignored population behind bars.

\section{Conclusions}

In conclusion, even though sex in correctional facilities is an under-researched subject, this study showed that it does occur within the confines of correctional facilities. This study has found that nearly all inmates $(98.6 \%)$ reported having sexual desire with watching the nakedness of others (44.4\%) and masturbation (38\%) as the commonest means of sexual expression and satisfaction of sexual desire within prison. Correctional facility authorities should develop programs aimed at improving the sexual health of inmates and consider the possibility of conjugal visitations/furloughs to prevent sexually deviant and improper ways of relieving sexual desire. Further, mixed methods studies could provide more nuanced insight.

\section{References}

1. Walmsley R. World prison population list. London: Institute for Criminal Policy Research. 2016

2. Chukwudi F. Challenges of reforms in the Nigerian Prison system: lessons from USA and South Africa. J Soc Sci 2012;4:5-46.

3. Marcum D, Castle TL eds. Sex in Prison: Myths and Realities. Lynne Rienner Publishers. 2014.

4. Lawan UM, Amole GT, Shuaib MJ. Sexual health of prison inmates: a case study of Kano Central Prison, North Western Nigeria. Afr J Reproduct Health 2016;20:93-103.

5. Gear S. Sex, sexual violence and coercion in men's prisons. Paper presented at Aids in Context International Conference, 4 - 7th April 2001. University of Witwatersrand, South Africa. 2001. Accessed on 7 July 2017. Available at from: https://csvr.org.za/docs/correctional/sexsexualviolence.pdf

6. Goyer KC. HIV/AIDS in Prison: Problems, Policies and Potentials. Paper presented at the Institute for Security Studies; 2003.

Sabitu K, Iliyasu Z, Joshua IA. An assessment of knowledge of HIV/AIDS and associated Risky Behavior among inmates of Kaduna Prison, the implications for prevention programs in Nigerian prisons. Nigerian J Med 2009;18:52-8.

8. Olusegun LI, Melvin OA. Prison Reform and HIV/AIDS in selected Nigeria Prisons. J Int Soc Res 2008;1:4.

9. Chima C, Labo HS, Adebayo S, et al. High HIV seroprevalence rates in prisons in Nigeria: a case of double sentencing for prison inmates. The Society for Family Health Rapid Assessment Report; 2009

10. National Bureau of Statistics. 2016 Accessed on 8 March 2019. Available from: http://www.nigerianstat.gov.ng

11. 11. Ajayi JO. Nigeria Prisons and the Dispensation of Justice. Int J Arts Human 2012;1:208-33.

12. Katsina Prison Services. 2018. Accessed on March 29, 2018. Available at: https://www.proshareng.com/admin/ upload/ report/10669-NBSPRISONFULLREPORT20112016proshare.pdf

13. Lwanga SK, Lemeshow S. Sample size determination in health studies, A practical manual. WHO 1991:1-3.

14. Richters J, Butler T, Yap L, et al. Sexual health and behaviour of New South Wales prisoners. Sydney: School of Public Health and Community Medicine, University of New South Wales; 2008, p.26.

15. Okochi CA, Oladepo O, Ajuwon AJ. Knowledge about AIDS and sexual behaviours of inmates of Agodi prison in Ibadan, Nigeria. Int Quarterly Comm Health Educ 2000;19:353-62.

16. Olugbenga-Bello AL, Adeoye OA, Osagbemi KG. Assessment of the Reproductive Health Status of Adult Prison Inmates in Osun State, Nigeria. Int J Reproduct Med 2013;451460.

17. Agbahowe SA, Ohaeri JU, Ogunlesi AO, Osahon R. Prevalence of psychiatric morbidity among convicted inmates in a Nigerian prison community. East Afr Med J 1998;75:1926.

18. Baillargeon J. Psychiatric disorder and repeated incarceration: The revolving prison door. Am J Psychiatr 1999;166:103-9.

19. Audu O, Ogbo SJ, Abdullahi AU, et al. Sexual Risk Behaviour and Knowledge of HIV/AIDS among male prison inmates in Kaduna State, North Western Nigeria. Int J Tropical Dis Health 


\section{3;3:57-67.}

20. Susan C. Impact a decade of global leadership and innovation. Final report on implementing AIDS prevention and care project. Family Health International 1997-2007.

21. Fadare RI, Akpor AO, Oshodi GE. Prevalence of HIV and Risk Factors among prison inmates in Akure, Ondo State, Nigeria. Int J Nurs Health Sci 2016;3:31-6.

22. Odujinrin MT, Adebajo SB. Social characteristics, HIV/AIDS knowledge, preventive practices and risk factors elicitation among prisoners in Lagos, Nigeria. West Afr J Med 2001;20:191-8

23. Aduba JN. A penological note on the prisons in Plateau State of Nigeria. Jos Lawyers Bi-Annual 1995;2.

24. Dambazau AB. Criminology and Criminal Justice. Ibadan, Spectrum Books. 2007

25. Jefferson AM, Martin TM. Prisons in Africa. Handbook on Prisons 2016;23:423-40.

26. Armiya'u AY, Obembe A, Audu MD, Afolaranmi TO. Prevalence of psychiatric morbidity among inmates in Jos maximum security prison. Open J Psychiat 2013;3:12-7.

27. Butler T, Gavin A, Stephen A, et al. Mental disorder in Australian prison. A comparison with a community sample. Austr/New Zeal J Psychiatr 2006;40:272-6.
28. Rabbebbe IB. Prevalence of psychiatric morbidity among convicted inmates in Maiduguri prison. An unpublished fellowship thesis submitted to the West African College of Physicians; 1999.

29. Kanyanya IM, Othieno CJ, Ndete DM. Prevalence of psychiatric morbidity among convicted sex offenders at Kamiti prison Kenya. East Afr Med J 2007;84:151-5.

30. The Chemistry and Chimera of Desire. 2019. Accessed on 20th February 2019.Available from: https://www.healthonline.com

31. Mahon N. New York Inmates HIV Risk behaviours: the implications for prevention policy and programs. Am J Public Health 1996;86:1211-5.

32. Power KG, Markova I, Rowlands A, et al. Sexual behaviours in Scottish prisons. BMJ 1991;302:1507.

33. Adesanya A, Ohaeri JU, Ogunlesi AO, et al. Psychoactive substance abuse among inmates of a Nigerian prison population. Drug Alcohol Depend 1997;47:39-44.

34. Kennedy A. Criminal Intimacy: Prison and the Uneven History of Modern American Sexuality. Gender and Society 2009;23:412-4.

35. Saliu A, Akintunde B. Knowledge, Attitude, and Preventive Practices among Prison Inmates in Ogbomoso Prison at Oyo State, South West Nigeria. Int J Reproduct Med 2014;363475. 